\title{
Evaluation of Harmful Factors of Municipal Solid Waste in Order to Be Valorized in Industrial Application ${ }^{+}$
}

\author{
Adriana Moanță ${ }^{1}$, Doru Vladimir Pușcașu 1, Gherghina Ciortan 1, Cristina Andreea Vijan 1, \\ Marina Martin 1, Jenica Paceagiu 1,*, Maria Paraschiv ${ }^{2}$, Mălina Prisecaru ${ }^{2}$ and Alina Elena Pop ${ }^{2}$ \\ 1 CEPROCIM SA, 6 Bdv. Preciziei, 062203 Bucharest, Romania; adriana.moanta@ceprocim.ro (A.M.); \\ doru.puscasu@ceprocim.ro (D.V.P.); gina.ciortan@ceprocim.ro (G.C.); andreea.vijan@ceprocim.ro (C.A.V.); \\ marina.martin@ceprocim.ro (M.M.) \\ 2 Faculty of Mechanical Engineering, University Politehnica of Bucharest, 313 Spl. Independentei, 060042 \\ Bucharest, Romania; mariaparaschiv@gmail.com (M.P.); malina_prisecaru@yahoo.com (M.P.); \\ alina_ela@yahoo.com (A.E.P.) \\ * Correspondence: jenica.paceagiu@ceprocim.ro \\ + Presented at the 15th International Symposium "Priorities of Chemistry for a Sustainable Development" \\ PRIOCHEM, Bucharest, Romania, 30th October-1st November 2019.
}

Published: 18 October 2019

Keywords: municipal solid waste; heavy metals; building materials; environment

Municipal waste disposal is an issue that is important to the management of any urban area. Cities without a functioning waste-disposal plan face the risk of diseases running rampant and economic activity grinding to a halt [1]. The safety and acceptability of many widely-used solid waste management practices are a serious concern from a public health perspective. The quantity and composition of municipal solid waste (MSW) varies from place to place, and bears a rather consistent correlation with the average standard of living. Waste recovery is one of the objectives of the national strategy. One method of recovery is the valorization of waste to produce fuel, while others suggest its incorporation into building materials [2-4].

The paper presents the chemical analysis and heavy metal composition of solid municipal waste for quantification of harmful compounds. Samples were obtained from a historical Romanian municipal solid waste disposal site.

Samples collected from 30 points were characterized from a heavy metal and corrosive agent $\left(\mathrm{Cl}^{-}\right)$content point of view. Specifically, analyses for determination of the calorific value, ash content and oxidic composition were carried out. In addition, determination of the heavy metal content (mercury, cadmium, cobalt, chromium, copper, manganese, nickel, lead, styrene, thallium, vanadium and zinc) was performed using graphite oven atomic absorption spectrometry, and a NovAA 400 hydride generator. To determine the calorific value of the waste, an IKA WERKE-type calorimetric pump was used. The chlorine content (considered a corrosive agent) and oxide composition of the ash was determined by wet chemistry.

The results obtained showed that:

- the content of heavy metals had a wide range of variation, with different domains depending on the type of element

- the minimum content of $\mathrm{Cl}$ determined was $0.68 \%$ and the maximum value recorded was $2.01 \%$

- the limits of variation for the lower calorific value were $3281-5790 \mathrm{kcal} / \mathrm{kg}$, while the higher calorific value varied in the range $590-5880 \mathrm{kcal} / \mathrm{kg}$

- in the case of ash, there was quite a wide variation in the limits of its oxide chemical composition 
Based on the complex characterization of the collected waste samples, and considering the wide range of variation in the values determined for each characteristic presented, it can be concluded that the deposited material was not homogeneous.

Acknowledgments: This work was financially supported by the Romanian competitiveness operational program through the knowledge transfer project CleanTech - POC - P40_308, SMIS:105958 (http://cleantech.pub.ro/).

\section{References}

1. Bastidas-Oyanedel, J.R.; Schmidt, J.E. Biorefinery: Integrated Sustainable Processes for Biomass Conversion to Biomaterials, Biofuels and Fertilizers; Springer International Publishing: Cham, Switzerland, 2019.

2. Sofi, M.; Sabri, Y.; Zhou, Z.; Mendis, P. Transforming Municipal Solid Waste into Construction Materials. Sustainability 2019, 11, 2661.

3. Joseph, A.; Snellings, R.; Van den Heede, P.; Matthys, S.; De Belie, N. The Use of Municipal Solid Waste Incineration Ash in Various Building Materials: A Belgian Point of View. Materials 2018, 11, 141.

4. Satoru, H. Waste Management Technologies in Japanese Cement Industry-From Manufacturing to EcofactuaringTM. J. Water Environ. Technol. 2004, 2, 31-36.

(c) 2019 by the authors. Licensee MDPI, Basel, Switzerland. This article is an open access article distributed under the terms and conditions of the Creative Commons Attribution (CC BY) license (http://creativecommons.org/licenses/by/4.0/). 